\title{
Biocontrol of Sclerotium oryzae by Pseudomonas fluorescens and Trichoderma spp. Isolated from Rice Rhizosphere of Indo- Burma Biodiversity Hotspot with Reference to Manipur
}

\author{
T. Subhalakshmi ${ }^{1}$ and S. Indira Devi ${ }^{2}$ \\ ${ }^{1}$ College of Horticulture, Thenzawl, Central Agricultural University Imphal, \\ Selesih, Aizawl- 796014, India \\ ${ }^{2}$ Microbial Resources Division, Institute of Bioresources and Sustainable Development, \\ An autonomous DBT Research Institute, Government of India \\ Takyelpat, Imphal- 795001, Manipur, India \\ *Corresponding author
}

Keywords

Pseudomonas

fluorescens,

Trichoderma spp.,

Stem rot, Rice,

Biocontrol,

Sclerotium oryzae

Article Info

Accepted:

20 January 2019

Available Online:

10 February 2019

\section{A B S T R A C T}

Stem rot of rice (Oryza sativae L.) caused by Sclerotium oryzae Catt. is found to occur frequently in Manipur infecting all cultivated lowland rice cultivars and become a major concern in rice production. Local strains of Pseudomanas fluorescens and Trichoderma collected from rice fields of Imphal East and Imphal West districts of Manipur were screened for their ability to control $S$. oryzae and production of different biocontrol mechanisms under laboratory conditions. Further, combined application of talc formulations of selected strains of $P$. fluorescens IE 62 and T. inhamatum (T 80) (based on in vitro antifungal activity, production of cell wall degrading enzymes and secondary metabolites) were assessed for their plant growth promotion and biocontrol ability under greenhouse and field conditions. Seed germination, root length, shoot length and plant height were enhanced by treatment with $P$. fluorescens IE 62 and T. inhamatum T 80 in vitro conditions as compared to single applications under greenhouse and field conditions. Field data revealed significant reduction in stem rot incidence, lesion number and size when applied in consortia. Percent reduction in lesion number and size were recorded as $35.15 \%$ \& $26.14 \%$ when applied with P. fluorescens IE 62 alone and $51.63 \%$ \& $14.43 \%$ with combined applications as compared to control plot indicating better biocontrol activity. The results indicated the effectiveness of combined application of local strains of $P$. fluorescens IE 62 and $T$. inhamatum T 80 resulting increased plant growth and control of $S$. oryzae and therefore can be used as potential bioagents for managing Stem rot disease in rice.

\section{Introduction}

Stem rot of rice caused by Sclerotium oryzae is present in all rice growing regions worldwide ( $\mathrm{Ou}, 1985)$. Its potential threat to reduction in rice yield has become a major concern in rice cultivation and production (Kumar et al., 2003). Yield losses ranges 
from 30-80\% in Phillippines (Ou 1985) and $10-70 \%$ in India (Singh and Pavgi 1966). In Manipur, it has infected all cultivated lowland rice cultivars either of local or exotic origin to Manipur (Konthoujam et al., 2007). Disease incidence of $40 \%$ was recorded at maturity stage. The exclusive and constant monoculture of rice with no alternate crop rotation practices coupled with the unavailability of disease resistant rice cultivars has aggravated the severity of stem rot of rice in the state which becomes a threat to production and yield of rice. The disease is now endemic in Manipur (Konthoujam 1998).

The use of beneficial micro-organisms as biocontrol agents has become more important in recent years not only to improve plant growth and to manage plant diseases but also to avoid environmental pollution. Being ecofriendly and cost effective strategy, it can be used in integration with other strategies for a greater level of protection with sustained rice yields. Among the biocontrol agents, Pseudomonas fluorescens and Trichoderma are most commonly used against rice diseases (Vasudevan et al., 2002). Pseudomonas spp. because of their ability to colonize the rhizosphere of host plants (widely prevalent in rice rhizosphere) and ability to produce a wide range of compounds inhibitory to a number of plant pathogens (Anjaiah et al., 1998; Weller 1988; Copper and Higgins 1993; Vidhyasekharan and Muthamilan 1995). Trichoderma spp. is one of the most potential fungal biocontrol agent used against soil/ seed borne fungal diseases of several crop plants (Kubicek et al., 2001). Combination of seed treatment, soil application and foliar spray with $P$. fluorescens recorded the minimum disease incidence of bacterial leaf blight with maximum yield (Jeyalakshmi et al., 2010). Increased root and shoot lengths, dry weight and plant height were recorded following treatment of plants with $P$. fluorescens and $T$. viride either alone or in combination when compared with control. Application of $P$. fluorescens and $T$. viride resulted in a significant reduction of sheath blight incidence (Mathivanan et al., 2005). Pseudomonas fluorescens inhibited the growth of the sheath blight pathogen, $R$. solani by the production of antibiotics (Gaffney et al., 1994) and siderophores (Savitry and Gnanamanickam, 1987) whereas $T$. viride degraded the chitin polymers from the cell wall of $R$. solani by secreting chitinase (Krishnamurthy et al., 1999). The use of multiorganisms as crop production and crop protection inputs is currently under practice in agriculture. Further combination of biocontrol agents was reported to offer an effective control of plant diseases (Duijff et al., 1999; De Boer et al., 2003). Combined inoculation of $P$. fluorescens with symbiotic nitrogen-fixing bacteria has been reported to promote plant growth and reduce the disease incidence (Nishijima et al., 1988). Increased root and shoot lengths, dry weight and plant height were recorded following treatment of plants with $P$. fluorescens and $T$. viride either alone or in combination with significant reduction of sheath blight incidence (Mathivanan et al., 2005). Combined use of biocontrol agents with different mechanisms is reported to improve disease control and also to overcome the inconsistent performance of the introduced biocontrol agents and could be more effective in controlling soil borne pathogens than a single agent (Nelson 2004). Strains of P. fluorescens and Trichoderma spp. are potential biocontrol agents for controlling foot rot disease in black pepper (Sharma et al., 2000), stem rot in groundnut (Manjula et al., 2004), wilt of tomato (Rini and Sulochana, 2007), etc. In North East India, such efforts have been tried by few with unsatisfactory output. Therefore, in this study, an attempt has been made to check the combined effect of local strains of $P$. fluorescens and Trichoderma spp. on crop 
growth and control of Stem rot of rice besides screening various biocontrol mechanisms.

\section{Materials and Methods}

Isolation and identification of causal organism of Stem rot of rice from infected rice fields

Stem rot infected leaf samples were collected from various locations of rice fields of Manipur. To isolate the pathogen, surface sterilized small bits of infected leaves were inoculated in PDA medium under aseptic condition and incubated at $28 \pm^{\circ} \mathrm{C}$ for $7-10$ days. Pathogen was then identified based on colony characteristics and morphological structures as well as molecular identification based on ITS amplification and was compared with the reference strain, ITCC 4107 obtained from IARI, New Delhi. The causal organism was found to be Sclerotium oryzae as confirmed by Koch's Postulates experiment.

Isolation of $\boldsymbol{P}$. fluorescens strain from rice rhizosphere of 5 different locations of Manipur

Soil samples from rice rhizosphere of five different locations namely Kongba Uchekon, Kongpal and Yaralpat of Imphal East and Phayeng and Takyelpat of Imphal West were collected to isolate the bacteria using serial dilution method in King's B medium. Single colonies showing characteristic fluorescens colour when exposed to UV at $365 \mathrm{~nm}$ were selected and sub cultured on LB broth which were then cryopreserved at $-80^{\circ} \mathrm{C}$ in $20 \%$ glycerol for further studies.

In vitro antagonistic activity of local $P$. fluorescens and Trichoderma spp. against $S$. oryzae

A total of $158 P$. fluorescens strains isolated from rice rhizosphere were screened for their antagonistic action against the fungus, $S$. oryzae by dual culture assay. The bacteria were streaked at the periphery of PDA plates (pH 6.1) with $9 \mathrm{~cm}$ diameter. After $24 \mathrm{~h}$ of incubation at $30^{\circ} \mathrm{C}$, a $6 \mathrm{~mm}$ disc of an actively growing culture of $S$. oryzae was inoculated at the center. Plates inoculated with $S$. oryzae alone were maintained as control. All the inoculated plates were further incubated for $72 \mathrm{~h}$ at $28^{\circ} \mathrm{C}$ and the colony diameter in each treatment was compared with that of control.The percentage inhibition was calculated with the help of the formula given by Whipps (1997).

A total of 5 IBSD Trichoderma isolates with proven biocontrol potential (Kamala and Indira, 2011) collected from different ecological niches of Manipur were screened for their antagonistic potential against $S$. oryzae. Mycelial discs of $6 \mathrm{~mm}$ diameter from actively growing cultures of Trichoderma spp. were inoculated at either end of PDA and incubated for 7 days at $28^{\circ} \mathrm{C}$. The plates were observed at regular intervals of $24 \mathrm{~h}$ and the antifungal activity was recorded on a 1-5 rating scale (Bell et al., 1982). PDA plates inoculated with $S$. oryzae alone were treated as control. The above experiments were repeated with three replications.

Compatibility test of Trichoderma spp. and P. fluorescens isolate

Trichoderma isolate $\mathrm{T} 80$ that showed maximum inhibition of $S$. oryzae in vitro was selected for checking compatibility with $P$. fluorescens isolate IE 62. For this, a small portion from the single colony of IE 62 was inoculated on one edges of the PDA plate. After one day, $6 \mathrm{~mm}$ disc of 7 days old mycelium of Trichoderma were taken and inoculated on the opposite side of the inoculated $P$. fluorescens isolate and incubated for seven days. Trichoderma spp. which can grow independently with the $P$. 
fluorescens isolate IE 62 on PDA plate was selected for effectivity trial under greenhouse and field conditions.

Screening of different biocontrol mechanisms exhibited by $P$. fluorescens isolates

Five different $P$. fluorescens strain and five IBSD Trichoderma isolates that showed maximum antagonistic activity against S.oryzae were screened for various biocontrol mechanisms which are given below:

\section{Protease and chitinase}

Protease activity of local strains of $P$. fluorescens and Trichoderma were determined from clearing zones in skim milk agar after five - seven days of incubation at $28^{\circ} \mathrm{C}$ (Berg et al., 2002).

Chitinase activity was tested on chitin minimal medium according to the method of Chernin et al., 1995 for bacterial isolates. Clearing zones indicating the enzymatic degradation were measured after1-7 days of incubation. For Trichoderma isolates, it was determined on chitin detection medium (Roberts and Selitrennikoff, 1988). Purple zone formation around the mycellia indicates chitinase production.

\section{Siderophore and Hydrogen cyanide (HCN) production}

Siderophore was assayed by plate method using Ternary complex chrome azurol $S$ (CAS), Fe3+/ Hexadicyl trimethyl ammonium bromide (HDTMA) as an indicator (Schwyn and Neilands 1987). Formation of a bright zone with a yellowish fluorescens in the dark blue medium indicates production of siderophore by the bacterial isolates. The HCN production by $P$. fluorescens was determined using picric acid solution by observing the colour change from yellow to brown and reddish brown. Scoring was done as weak- yellow to light red, moderatebrown, strong- reddish brown (Millar and Higgins 1970).

\section{Phosphorus Solubilization (PS)}

Bacterial cultures were streaked on Pikovskayas agar (PKA) to check phosphorus solubilizing ability. Those isolate forming clear zones were scored positive (Pikovskaya 1948)

\section{Sequence analysis}

The identity of the bacterial isolate IE 62 was confirmed by $16 \mathrm{~S}$ rDNA sequences and BIOLOG based identification and showed it to be $97 \%$ similar to that of Pseudomonas fluorescens (EU5544291). ITS amplification of the isolated fungus from stem rot infected leaf samples showed that the sequence was similar to that of Ceratorhiza oryzae - sativae (FJ6672571) showing 100\% similarity which is a synonym of Sclerotium oryzae sativae. ITS amplification of the isolated Trichoderma isolate T 80 showed that the sequence was similar to that of Trichoderma inhamatum (GQ426033) showing 97\% similarity.

Plant growth and disease control ability trial in phytochamber, greenhouse and field

Rice var. KD was used as a test crop for all the experiments. The bacterial and fungal formulation with presterilized talc powder was prepared as described by Vidyasekaran et al., (1997). The population of $P$. fluorescens IE62 in the talc formulation was $13.3 \times 10^{10}$ $\mathrm{cfu} / \mathrm{g}$ and for T.inhamatum T80 it was $1 \times 10^{6}$ conidia/ $\mathrm{ml}$ ) at the time of use. For observing seed germination, root and shoot length, seeds were soaked for 15 minutes in formulation (20 $\mathrm{g} \mathrm{l}^{-1}$ ) of $P$. fluorescens IE62 and 
T.inhamatum T80 and incubated in a growth chamber at $28 \pm 2^{\circ} \mathrm{C}$. The types of treatment were i) P. fluorescens IE62, ii) P. fluorescens IE62 + T.inhamatum T80 and iii) Control. Germination rate, root and shoot length were recorded after 5-6 days.

Pot experiment was laid out in a CRD with three replications ( 3 plants/ pot sizes of $25 \mathrm{x}$ $30 \mathrm{~cm}$ ) containing mixture of FYM, sand and soil to the ratio of 1/2:1:2 in greenhouse. The pathogen inoculum (S.oryzae) cultured in autoclaved rice grains were inoculated in the potting mixture. After two days, formulations were applied to the soil (15g/pot) and germinated rice seedlings of 15 days old were transferred to the potting mixture after giving root dip treatment $\left(20 \mathrm{~g} \mathrm{l}^{-1}\right)$ for 15 mins. The treatments were i) P. fluorescens -IE62 (soil application and root dip treatment), ii) S.oryzae (S.o); (soil application), iii) S.oryzae (S.o) + P. fluorescens IE62+ Trichoderma inhamatum T80 (soil application + root dip treatment) and iv)Control (non-treated).

In order to confirm the result obtained in greenhouse trial, field experiment (plot sizes;15 x $20 \mathrm{ft}$ ) laid out in a RBD was conducted for two consecutive years, 2010 and 2011 in Stem rot prone areas of Phayeng, Imphal West District of Manipur. FYM (100 $\mathrm{kg} / \mathrm{ha}$ ) was added to the plots one month ahead of transplanting the seedlings. The treatments given were as follows:

i) $\quad P$. fluorescens IE62 (seed treatment + soil application + root dip treatment)

ii) $\quad P$. fluorescens IE62 + T.inhamatum T80 (seed treatment + soil application + root dip treatment

iii) Control (seeds soaked in LB broth)

The observations were recorded on different parameters viz. plant growth, stem rot incidence and lesion formation. Stem rot incidence was calculated by applying the standard formula given by Mc Kinney, 1923.

\section{Statistical analysis}

Different treatments in all the experiments were arranged in a completely randomized block design. Values given in the tables are means based on replicates. Data from all the experiments were analyzed by analysis of variance (ANOVA) using Genstat 5 statistical package. Least significant difference (LSD) at $5 \%$ level of significance $(P=0.05)$ was used to compare the mean values of different treatments in an experiment. Pooled data of two consecutive years of the greenhouse and field experiments were subjected to ANOVA.

\section{Results and Discussion}

In vitro antifungal activity of local $P$. fluorescens isolates and Trichoderma spp. against $S$. oryzae

Among the $158 P$. fluorescens strain screened for antifungal activity against $S$. oryzae, five isolates showed maximum biocontrol potentials. Among them, P. fluorescens IE 62 showed maximum inhibition of $S$. oryzae with $40.52 \%$ (Fig. 1A) followed by IE 182 $(38.26 \%)$ and IE $23(28.56 \%)$ respectively (Table 1). A potential IBSD Trichoderma isolates, $T$. inhamatum $\mathrm{T} 80$ showed maximum mycellial inhibition of $S$. oryzae with $80.23 \%$ (Fig. 1B). Antifungal activity of the local strains of $P$. fluorescens was compared with the reference $P$. fluorescens strain- 103 obtained from IMTECH, Chandigarh which failed to inhibit growth of $S$. oryzae even after seven days of incubation (Table 1, Fig. 1C).

\section{Screening for various biocontrol mechanisms of $\boldsymbol{P}$. fluorescens strain and Trichoderma T80}

All the five isolates showed protease and siderophore production. IE 182 did not show chitinase activity. Hydrogen cyanide 
production was shown by two isolates namely IE 17 and IE 182 whereas phosphorus solubilization was shown by isolates IE 18, IE 62 and IE 182 (Table 2). Very low protease activity was exhibited by $P$. fluorescens strain 103 with clearance zone of only $5 \mathrm{~mm}$ which was lower as compared to all the five isolates screened. Trichoderma T80 showed protease activity with clearance zone diameter of 37.67 $\mathrm{mm}$ and chitinase activity with purple zone of $81.33 \mathrm{~mm}$.

In vitro compatibility of $P$. fluorescens IE 62 and $T$. inhamatum $T 80$

Based on antifungal and biocontrol mechanisms exhibited by different $P$. fluorescens strain, isolate IE 62 was selected for conducting greenhouse and field trials. For combined effectiveness trial, compatibility test of T. inhamatum T 80 and P. fluorescens isolate IE was done and were found compatible to each other (Fig. 1D). Thus, $T$. inhamatum $\mathrm{T} 80$ was selected for combined application with $P$. fluorescens isolate IE 62 for greenhouse and field trial.

Effect of single and combined application on seed germination, root and shoot length of rice seedlings var. $K D$ in vitro conditions

Both single and combined treatment of IE 62 and $\mathrm{T} 80$ significantly enhance the germination rate. Single application with IE 62 gave $90.92 \%$ seed germination and combined application (IE 62+ $\mathrm{T}$ 80) gave $90 \%$ seed germination enhancing it by $9.32 \%$ and $8.89 \%$ respectively as compared to control which recorded $82.45 \%$ seed germination (Table 3). Length of root and shoot of the treated seedlings were recorded one week after germination. Both single and combined application significantly increased the root and shoot length as compared to control. Percent increase in root length (50.6 $\mathrm{mm})$ was 17.38 and shoot length $(8.55 \mathrm{~mm})$ -
3.27 respectively in combined application as compared to single application which recorded $44.4 \mathrm{~mm}$ root length and $52 \mathrm{~mm}$ shoots length with increase of $0.59 \%$ and $3.27 \%$ respectively (Table $3 ; \mathrm{P}_{(0.05)}=0.0011$ root), 4.38-shoot).

Effect of treatment of $\boldsymbol{P}$. fluorescens IE 62 and Trichoderma T 80 on height of rice cultivar KD in greenhouse and field trial

Height of rice plant was recorded 35 days after planting under green house conditions (Table 4). Plant height was found to be significantly increased with both single $(58.76 \mathrm{~cm})$ and combined treatment $(59.9 \mathrm{~cm})$, combined application being more effective with $4.84 \%$ increase in height and single treatment - $3.01 \%$ as compared to control which recorded height of $57 \mathrm{~cm}$ only (Table $\left.4 ; \mathrm{P}_{(0.05)}=1.19\right)$. In order to confirm the result obtained in greenhouse trial, field experiment was conducted at Imphal West district of Manipur for two consecutive years i e 2010 \& 2011. Data represented in table 4 is pooled data of two years. Plant height was recorded three months after planting. In this experiment, combined application(IE $62+\mathrm{T}$ 80) showed significant increase in plant height with $8.84 \%$ whereas plants treated with IE 62 alone showed only $2.48 \%$ as compared to control (Table 4; $\mathrm{P}_{(0.05)}=4.26$ ).

Effect of treatment of Pseudomonas and Trichoderma on lesion formation of $S$. oryzae under green house and field conditions

Number and size of lesions produced by $S$. oryzae on infected leaf samples were recorded 45 days after giving secondary infection by foliar spray method. Both single and combined treatment significantly reduced lesion number and lesion size as compared to control which is infected only with S.oryzae (Figure 3). Combined treatment (S.o+ IE 62+ 
T 80) showed significant difference recording $38.83 \%$ and $49.23 \%$ reduction in lesion number and size respectively when compared with single treatment of $22.17 \%$ and $27.69 \%$ reduction irrespective of lesion number $(\mathrm{P}$ $\left.{ }_{(0.05)}=0.0024\right)$ and size $\left(\mathrm{P}_{(0.05)}=0.02\right)$.

In field trial, similar observations were obtained. Infected plant samples of 45 days old were collected from different treatments (Figure 4) and number and size of lesions were recorded. Field data indicated significant reduction in both lesion number and size by single treatment with IE 62 as well as combined treatment with T. inhamatum (T 80) as compared to control field (Figure 4a) which was infected only with $S$. oryzae under natural conditions. Single treatment (IE 62) recorded less lesion number (14.67) and lesion size $(5.99 \mathrm{~mm})$ with \% reduction of 51.63 and 26.14 respectively (Figure 3, 4b) as compared to combined treatment (IE 62+ T 80) which recorded 19.67 lesion number and $6.94 \mathrm{~mm}$ lesion size with $35.15 \%$ and $14.43 \%$ decrease respectively (Figure 2, 3 and 4c) and the treatments were found statistically significant.

Effect of treatment of Pseudomonas and Trichoderma on stem rot incidence in greenhouse and field conditions

Incidence of Stem rot was recorded for each treatment after two months of planting in greenhouse conditions. Combined application $($ S.o + IE $62+\mathrm{T}$ 80) resulted in less disease incidence $(43.95 \%)$ and single application (S.o + T 80) recorded $61.97 \%$ as compared to control which recorded stem rot incidence of $72 \%$ (Table 5). This result clearly indicates that combined application of $P$. fluorescens IE 62 and Trichoderma T 80 gave better control of stem rot as compared to single application.

Similar observations were obtained from field trial with combined application recording stem rot incidence of $40.47 \%$ than single treatment with $P$. fluorescens IE 62 that recorded $48.28 \%$ as compared to control which recorded $100 \%$ stem rot incidence (Table 5).

The present findings identified many potential Pseudomonas strains from rice rhizosphere of different locations of Manipur of which many of them were antagonistic against the newly isolated pathogen ie $S$. oryzae. A total of twenty $P$. fluorescens isolates were found to inhibit $S$. oryzae in dual culture assay with differing range of inhibition zone.

The bacterial isolates were found to exhibit multiple cell wall degrading enzymes and secondary metabolites which might have contributed in pathogenesis. In the present study, the selected antifungal $P$. fluorescens isolates IE 62 were observed to produce protease, chitinase, siderophore, $\mathrm{HCN}$ in vitro, which might have contributed for their maximum biocontrol ability in addition to antibiotics. A positive relationship was observed between the antifungal activity of chitinolytic $P$. fluorescens isolates and their level of chitinase production (Velazhahan et al., 1999). In contrast to the mycelial inhibition in dual cultures, all the five $P$. fluorescens isolates differed in their biocontrol ability possibly due to the differences in root colonization and production of antifungal metabolites in natural environments. HCN and siderophores produced by Pseudomonas spp. were also involved in their antifungal activity. Voisard et al., (1989) observed that supression of black rot of tobacco was due to the production of HCN by $P$. fluorescens which also induced resistance in the host plant. Antagonistic assay of $T$. inhamatum $\mathrm{T} 80$ against $S$. oryzae in vitro conditions resulted in maximum inhibition of $S$. oryzae possibly due to the parasitization and colonization of sclerotia as reported by Haroon Usmani (1980) and Henis et al., (1983). 
Combination of different biocontrol agents is often observed as an effective means for sustained disease control. Combined application of $P$. fluorescens IE 62 and $T$. inhamatum $\mathrm{T} 80$ resulted in improved biocontrol both in terms of plant growth and disease management than single application with only $P$. fluorescens IE 62 as shown by geenhouse screening and field trials. Seed germination, root and shoot length were enhanced by combined treatment as compared to single treatment. Similar observations were obtained by Singh and Arora (2001) who showed that growth parameter and vigor index were high in Trichoderma sp and $P$. fluorescens treatment. Plant growth may have improved due to growth regulators produced by the antagonists together with their continuous supply to the developing plants as a result of the intimate contact between the seeds and the biocontrol agent (Tarek and Moussa, 2002). Application of P. fluorescens and $T$. viride either alone or in combination showed a positive influence in improving growth attributes in rice such as shoot and root lengths and dry weight, plant height and time up to $50 \%$ flowering when compared with fungicide treatment and control.

Table.1 Antagonistic activity of 20 selected local rhizobacteria in dual plate assay

\begin{tabular}{|c|c|c|c|}
\hline \multirow[t]{2}{*}{ Sl. No } & \multirow{2}{*}{$\begin{array}{l}\text { Bacterial } \\
\text { isolates }\end{array}$} & \multicolumn{2}{|c|}{ Antagonistic activity } \\
\hline & & S. oryzae & $\%$ of growth inhibition* \\
\hline 1. & IE 1 & + & 12.36 \\
\hline 2. & IE 2a & + & $10.1 \pm 0.25$ \\
\hline 3. & IE 14 & + & $10.42 \pm 0.97$ \\
\hline 4. & IE 16 & + & $9.33 \pm 0.85$ \\
\hline 5. & IE 17 & ++ & $25.49 \pm 0.41$ \\
\hline 6. & IE 18 & ++ & $27.15 \pm 1.31$ \\
\hline 7. & IE 23 & ++ & $28.56 \pm 1.03$ \\
\hline 8. & IE 182 & ++ & $38.26 \pm 1.09$ \\
\hline 9. & IE 271 & ++ & $17.91 \pm 0.05$ \\
\hline 10. & IE 62 & +++ & $40.52 \pm 0.84$ \\
\hline 11. & IE 326 & ++ & $22.91 \pm 1.5$ \\
\hline 12. & IE 332 & ++ & $20.23 \pm 0.42$ \\
\hline 13. & IE 323 & +++ & $36.78 \pm 0.46$ \\
\hline 14. & IB 137 & + & $14.78 \pm 0.29$ \\
\hline 15. & IB 371 & + & $11.15 \pm 1.12$ \\
\hline 16. & IB 477 & ++ & $18.95 \pm 0.11$ \\
\hline 17. & IB 488 & ++ & $19.18 \pm 0.2$ \\
\hline 18. & IB 546 & ++ & $20.61 \pm 0.27$ \\
\hline 19. & C 37 & + & $14.5 \pm 0.65$ \\
\hline 20. & C 51 & + & $13.05 \pm 1.54$ \\
\hline 21 & Control & - & - \\
\hline $\operatorname{LSD}(P=0.05)$ & & & 1.16 \\
\hline
\end{tabular}


Table.2 Biocontrol mechanisms of exhibited by local rhizobacterial isolates

\begin{tabular}{|c|c|c|c|c|c|c|c|}
\hline \multirow[t]{3}{*}{ Sl. No } & \multirow[t]{3}{*}{ Rhizobacteria } & \multicolumn{6}{|c|}{ Different biocontrol mechanisms exhibited by local rhizobacterial isolates. } \\
\hline & & \multicolumn{4}{|c|}{ Zone diam. $(\mathrm{mm})$} & \multirow{2}{*}{$\mathrm{HCN}$} & \multirow{2}{*}{ PS } \\
\hline & & Protease* & Chitinase* & Siderophore* & Glucanase & & \\
\hline 1. & IE 1 & $25 \pm 0$ & $10 \pm 1.15$ & $18 \pm 0$ & ++ & - & - \\
\hline 2 & IE $2 \mathrm{a}$ & $15 \pm 0$ & $12 \pm 0$ & $12 \pm 0.76$ & + & - & - \\
\hline 3. & IE 14 & $23 \pm 0.86$ & $12 \pm 0.86$ & $17 \pm 0.86$ & + & - & - \\
\hline 4. & IE 16 & $24 \pm 0.69$ & $10 \pm 1.73$ & $15 \pm 0$ & ++ & - & - \\
\hline 5 & IE 17 & $20 \pm 2.42$ & $10 \pm 0.86$ & - & ++ & + & - \\
\hline 6 & IE 18 & $23 \pm 1.15$ & - & 12.0 & ++ & - & + \\
\hline 7 & IE 23 & $24 \pm 0.28$ & - & $17 \pm 0.57$ & ++ & - & - \\
\hline 8 & IE 271 & $21 \pm 0.28$ & - & 16.0 & + & + & + \\
\hline 9 & IE 62 & $18 \pm 0$ & $15.3 \pm 0.4$ & $13.3 \pm 0.40$ & ++ & + & + \\
\hline 10 & IE 326 & $16 \pm 0$ & $10 \pm 0$ & $15 \pm 0.57$ & - & + & - \\
\hline 11 & IE 332 & $16 \pm 0.58$ & $12 \pm 0.86$ & $14 \pm 0$ & - & + & - \\
\hline 12 & IE 323 & $15 \pm 0.17$ & $10 \pm 1.15$ & $15 \pm 0.58$ & +++ & + & + \\
\hline 13 & IB 477 & $22.67 \pm 1.33$ & $10.1 \pm 0.73$ & $15 \pm 0.09$ & ++ & - & + \\
\hline 14 & IB 488 & $19.3 \pm 0.43$ & $12.9 \pm 0.06$ & $12 \pm 0$ & - & + & + \\
\hline 15 & IB 546 & $14.5 \pm 0$ & - & $14.9 \pm 0.03$ & ++ & + & - \\
\hline 16. & IB 137 & $14 \pm 1.15$ & $7.0 \pm 0.57$ & - & + & + & - \\
\hline 17 & IB 371 & $16 \pm 0.86$ & $12 \pm 0.57$ & $14 \pm 0.57$ & + & + & - \\
\hline 18. & IE 182 & $13 \pm 0.57$ & - & $15.0 \pm 0.28$ & + & + & - \\
\hline 19. & C 37 & $18 \pm 0.57$ & $10 \pm 0.57$ & $12 \pm 1.44$ & - & + & + \\
\hline 20. & C 51 & $14 \pm 0$ & - & - & - & - & - \\
\hline \multicolumn{2}{|c|}{ L.S.D $(P=0.05)$} & 3.82 & 1.0 & 4.94 & & 1.0 & \\
\hline
\end{tabular}

Table.3 Effect of treatment of Pseudomonas and Trichoderma on seed germination, root and shoot length of rice var. KD after 7 days of incubation

\begin{tabular}{|c|c|c|c|c|c|c|}
\hline \multirow[t]{2}{*}{ Sl.no } & \multirow{2}{*}{$\begin{array}{l}\text { Type of seed } \\
\text { treatment }\end{array}$} & \multirow{2}{*}{$\begin{array}{l}\% \text { of seed } \\
\text { germination }\end{array}$} & \multicolumn{2}{|r|}{ Root } & \multicolumn{2}{|r|}{ Shoot } \\
\hline & & & $\begin{array}{l}\text { Length } \\
(\mathrm{mm}) *\end{array}$ & $\begin{array}{l}\% \text { increase in } \\
\text { ength }(\mathbf{m m}) *\end{array}$ & $\begin{array}{l}\text { Length } \\
(\mathrm{mm}) *\end{array}$ & $\begin{array}{l}\text { \%increase in } \\
\text { length }(\mathrm{mm}) *\end{array}$ \\
\hline 1. & IE 62 & $90.92 \pm 0.47$ & $\begin{array}{l}44.3 \pm \\
8.45\end{array}$ & 17.38 & $\begin{array}{l}52.0 \pm \\
2.31\end{array}$ & 3.27 \\
\hline 2. & IE $62+\mathrm{T} 80$ & $90 \pm 0$ & $\begin{array}{l}50.6 \pm \\
6.36\end{array}$ & 0.59 & $\begin{array}{l}55.0 \pm \\
0.58\end{array}$ & 8.55 \\
\hline 3. & Control & $82.45 \pm 4.33$ & $\begin{array}{l}36.6 \pm \\
1.67\end{array}$ & - & $\begin{array}{l}50.3 \pm \\
2.33\end{array}$ & \\
\hline \multicolumn{2}{|c|}{$\operatorname{LSD}(P=0.05)$} & 2.18 & 4.16 & & 6.48 & \\
\hline
\end{tabular}


Table.4 Effect of treatment of Pseudomonas and Trichoderma on plant height under green house and field conditions for two consecutive years 2010 \& 2011

\begin{tabular}{|l|l|l|l|l|l|}
\hline Sl. no & Treatment & \multicolumn{3}{|c|}{ Greenhouse trial } & \multicolumn{2}{|c|}{ Field trial } \\
\cline { 3 - 7 } & & $\begin{array}{l}\text { Plant ht. }(\mathbf{c m})^{*} \mathbf{6 0} \\
\text { DAP }\end{array}$ & $\begin{array}{l}\text { \% increase in } \\
\text { ht. }\end{array}$ & $\begin{array}{l}\text { Plant } \\
\text { (cm) } \\
\text { 90 DAP }\end{array}$ & $\begin{array}{l}\text { \% increase } \\
\text { in ht. }\end{array}$ \\
\hline 1. & IE 62 & $58.76 \pm 2.28$ & 3.01 & $64.5 \pm 2.05$ & 2.48 \\
\hline 2. & $\begin{array}{l}\text { IE 62+ T } \\
80\end{array}$ & $59.9 \pm 1.19$ & 4.84 & $69.0 \pm 2.12$ & 8.84 \\
\hline 3. & Control & $57.0 \pm 4.04$ & - & $62.9 \pm 1.17$ & - \\
\hline LSD (P= 0.05) & 1.23 & & 4.26 & \\
\hline
\end{tabular}

*Mean of three replications; DAP- Days after planting

Table.5 Stem rot incidence in two months old rice plant (cv. KD) under greenhouse and field conditions after treatment with P. fluorescens IE 62 and T. inhamatum T 80

\begin{tabular}{|l|l|l|l|}
\hline Sl.no. & Treatment & $\begin{array}{l}\text { Stem rot incidence }(\%) \\
\text { Greenhouse }\end{array}$ & Field \\
\hline 1. & IE 62 & $37.1 \pm 2.0$ & - \\
\hline 2. & S. o + IE 62 & $61.97 \pm 0.99$ & $48.28 \pm 1.51$ \\
\hline 3. & $\begin{array}{l}\text { S.o + IE 62 }+ \\
\text { T } 80\end{array}$ & $43.95 \pm 2.07$ & $40.47 \pm 1.26$ \\
\hline 4. & Control (S. o) & $72 \pm 1.75$ & $100 \pm 0$ \\
\hline LSD (P= $\mathbf{0 . 0 5})$ & 0.002 & 0.084 \\
\hline
\end{tabular}

Fig.1 Antagonistic potential of A. P. fluorescens IE 62 against S. oryzae, B. Trichoderma T 80 against $S$. oryzae, C. P. fluorescens 103 against $S$. oryzae and D. Compatibility of P. fluorescens IE 62 and Trichoderma T 80
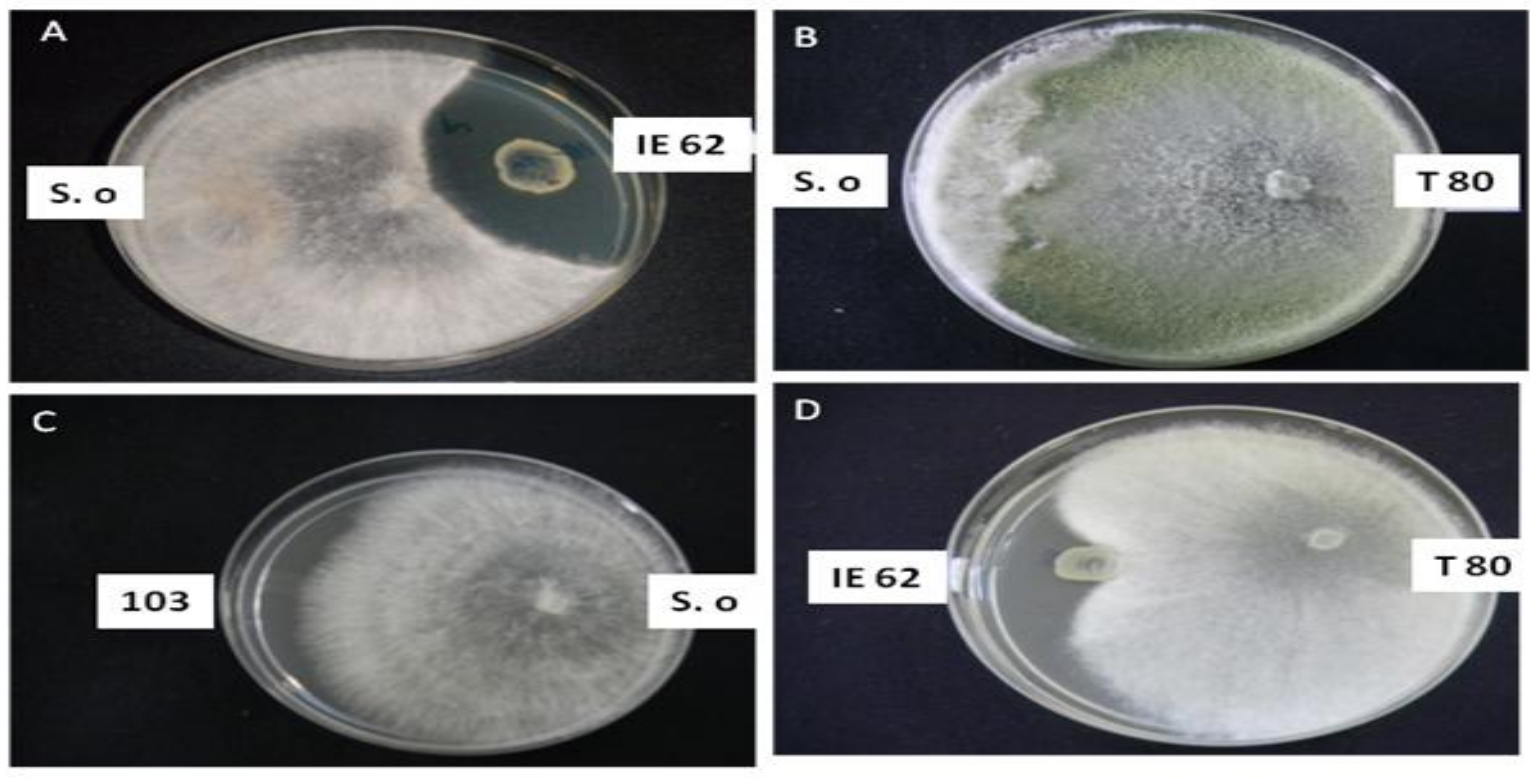
Fig.2 Effect of single and combined application of $P$. fluorescens IE 62 and Trichoderma T 80 on lesion formation of $S$. oryzae under greenhouse conditions

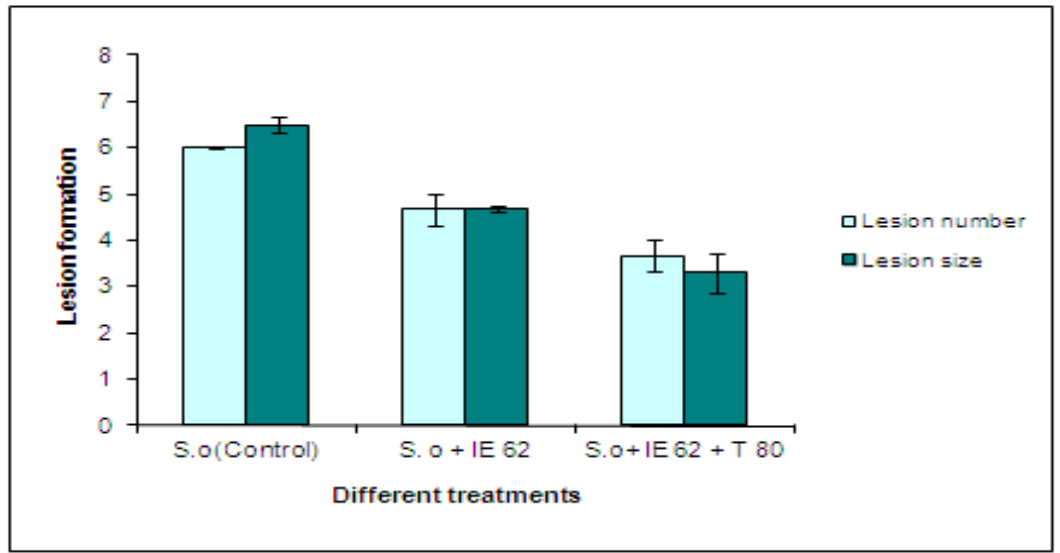

Fig.3 Effect of single and combined application of $P$. fluorescens IE 62 and Trichoderma T 80 on lesion formation of $S$. oryzae under field conditions

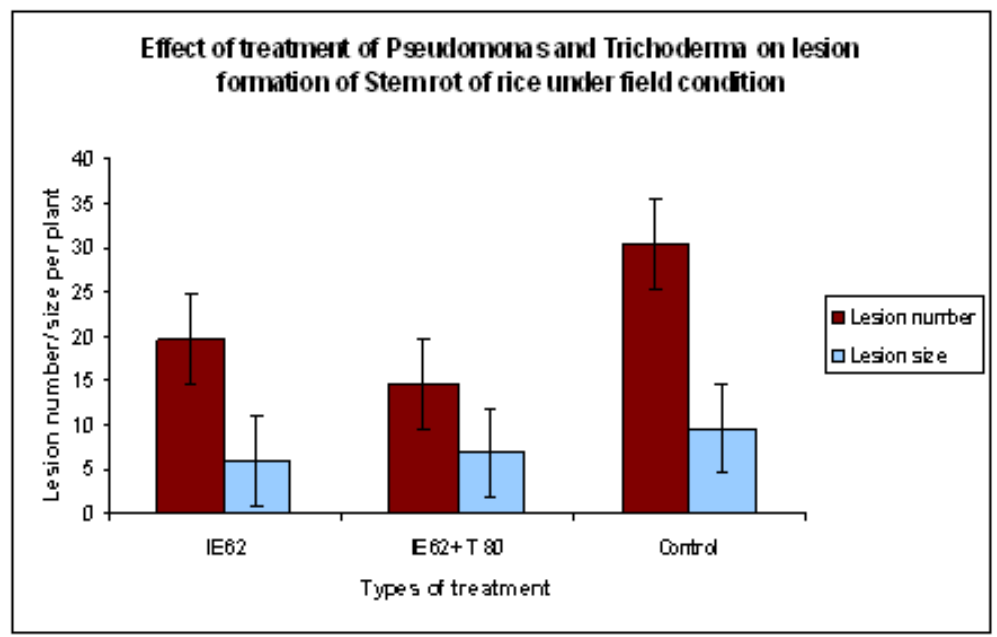

Fig.4 Stem rot infected rice plant collected from a. Control plot, b. P. fluorescens IE 62 treated plot and c. P. fluorescens IE 62 and Trichoderma T 80 treated plot
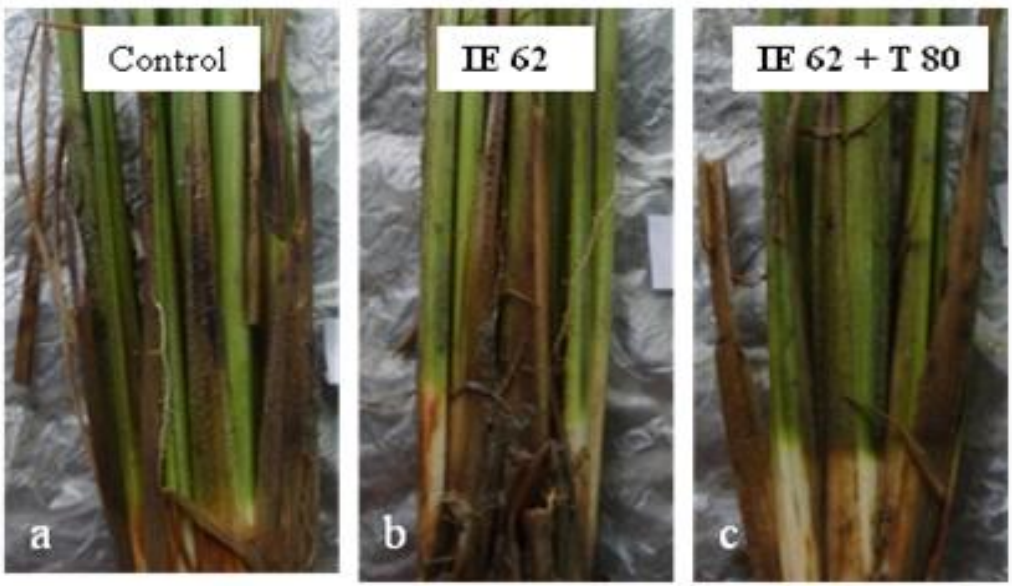
These growth promotion activities could be due to secretion of plant growth-promoting substances and plant growth hormones by the rhizosphere micro-organisms as demonstrated by Ureta et al., 1995). The growth promotion in rice was high following the combined application of $P$. fluorescens and $T$. viride indicating that synergism existed between the two beneficial micro-organisms as shown for the combination of other micro-organisms (Camprubi et al., 1995). Application of $P$. fluorescens and $T$. viride significantly reduced the sheath blight disease incidence with maximum reduction in disease severity with combined application of $P$. fluorescens and $T$. viride. Our results support the earlier observations that a combination of biocontrol agents with different mechanisms of disease control will have an additive effect and results in enhanced disease control as compared to their individual application (Guetsky et al., 2002).

In conclusion, the present study identified local strains, $P$. fluorescens IE62 and T.inhamatum T80 that could control Stem rot of rice in Manipur and can be easily integrated into the existing production practices. Biocontrol ability may be due to well adaptation to the existing environment as revealed by field data and also due to pathogen specificity and location specific. Moreover better biocontrol efficacy was exhibited when applied in consortia in greenhouse and field trial which indicated better prospect for field applications. Development of biological control product based on these strains needs further research on repeated trail in field to study the best formulation and to ensure success of the control mechanism of the isolated rhizosphere organisms.

\section{Acknowledgement}

We are grateful to Department of Biotechnology for giving financial assistance.

\section{References}

Abdul Baki, AA, Anderson JD. 1973. Vigour determination in soybean seed by multiple criteria, Crop Sci.13:630-633.

Anjaiah V, Koedam N, Nowak-Thompson B, Loper JE, Hofte M, Tambong JT, Cornelis P. 1998. Involvement of phenazines and anthranilate in the antagonism of Pseudomonas aeruginosa PNA1 and Tn5 derivative toward Fusarium spp. and Pythium spp. Molecular Plant-Microbe Interactions. 11:847- 854.

Bell DK, Wells HD, Markham CR.1982. In vitro antagonism of Trichoderma spp. against six fungal pathogens. Phytopathology. 72:379-382.

Berg G, Roskot N, Steidle A, Eberl L, Zock A, Smalla K. 2002. Plant-dependent genotypic and phenotypic diversity of antagonistic rhizobacteria isolated from different Verticillium host plants. Applied and Environmental Microbiology.68:3328-3338.

Camprubi A, Calvet C, Estaun V. (1995) Growth enhancement of Citrus reshni after inoculation with Glomus intraradices and Trichoderma aureoviride and associated effects on microbial populations and enzyme activity in potting mixes. Plant Soil 173:233-238.

Chernin LS, DE LA Fuent L, Sobolev V, Haran S, Vorgias Oppenheim AB, Chet I.1995. Molecular cloning, structural analysis, and expression in Escherichia coli of a chitinase gene from Enterobacter agglomerans. Applied and Environmental Microbiology. 63(3):834-839.

Copper AL, Higgins KP.1993. Application of Pseudomonas fluorescens isolates to wheat as potential biological control agents against take-all. Plant Pathology. 42: 560-567.

De Boer M, van der Sluis I, van Loon LC, 
Bakker PAHM. 2003. Combining fluorescent Pseudomonas spp. strains to enhance suppression of Fusarium wilt of radish. European Journal of Plant Pathology. 105: 201-210.

Duijff BJ, Recorbet G, Bakker PAHM, Loper JE, Lemanceau P. 1999. Microbial antagonism at the root level is involved in the suppression of Fusarium wilt by the combination of non-pathogenic Fusarium oxysporum Fo47 and Pseudomonas putida WC358. Phytopathology. 89:1073-1079.

Guetsky R, Steinberg D, Elad Y, Fischer E, Dinoor A. 2002. Improving biological control by combining biocontrol agents each with several mechanisms of disease suppression. Phytopath. 92: 976- 985.

Haroon Usmani SM.1980. Studies on the biological control of Sclerotium oryzae catt the cause of stem rot of rice. $\mathrm{Ph}$. D.Thesis., University of Karachi. p- 23.

Henis Y, Adams PB, Lewis JA, Papavizas GC. 1983. Penetration of sclerotia of Sclerotium rolfsii by Trichoderma spp. Phytopatho. 73:1043- 1046.

Jeyalakshmi C, Madhiazhagan K, Rettinassababady C. 2010. Effect of different methods of

application of Pseudomonas fluorescens against bacterial leaf blight under direct sown

rice. Journal of Biopesticides. 3(2): 487 - 488

Kamala Th. Indira S. 2011.Evaluation of indigenous Trichoderma isolates from Manipur as biocontrol agent against Pythium aphanidermatum on common beans. 3 Biotech, 1:217- 225.

Konthoujam J.1998.Pest and disease surveillance report for the year 19921997. Pest Surveillance and Mobile Squad, Mantripukhri, Department of Agriculture, Govt. of Manipur. pp. 5-10. Konthoujam J, Chhetry GKN, Sharma R.2007.Symptomatological significance and characterization of susceptibility/ resistance group among low land rice cultivars towards stem rot of rice in Manipur valley. Indian Phytopath. 60(4): 478- 481.

Kubicek CP, Mach RL, Peterbauer CK, Lorito M. 2001. Trichoderma: From genes to biocontrol. Plant Patho. 83:11- 24.

Manjula K, Krishna Kishore G, Girish AG, Singh SD. 2004.Combined application of Pseudomonas fluorescens and Trichoderma viride has an improved biocontrol activity against Stem rot in groundnut. Plant Pathology Journal 20(1):75- 80.

Mathivanan N, Prabavathy VR, Vijayanandraj VR. 2005. Application of Talc Formulations of Pseudomonas fluorescens Migula and Trichoderma viride Pers. ex S.F. Gray Decrease the Sheath Blight Disease and Enhance the Plant Growth and Yield in Rice J. Phytopathology. 153: 697-701.

Mc Kinney. 1923. Influence of temperature and moisture on the influence of wheat seedling by Helminthosporium sativa. J. Agric. Res. 26:196-217.

Millar RL, Higgins VJ.1970. Association of cyanide with infection of birds foot trefoil by Stemphyllium loti. Phytopath. 60:104-110.

Nelson EB.2004. Microbial dynamics and interactions in the spermosphere. Ann. Rev. of Phytopath. 42:271-309.

Nishijima F, Evans WR, Vesper SJ. 1988. Enhanced nodulation of soybean by Bradyrhizobium in the presence of $P$. fluorescens. Plant Soil.111:149-150.

$\mathrm{Ou}$ SH. 1985. Rice Diseases in Commonwealth Mycological Institute, Kew, Survey, England, eds. 380p.

Rini CR, Sulochana KK. 2007. Usefulness of Trichoderma and Pseudomonas against Rhizoctonia solani and Fusarium oxysporum infecting tomato. J. of Trop. Agric. 45 (1-2):21- 28. 
Roberts WK, Selitrennikoff CP. 1988.Plant and bacterial chitinases differ in antifungal activity. J Gen Microbiol. 134:169-176.

Schwyn B, Neilands JB. 1987. Universal chemical assay for the detection and determination of siderophores. Annals of Biochemistry. 160:46-56.

Sharma YR, Rajan PP, Beena N, Diby P, Anandaraj M. 2000. Role of rhizobacteria on disease suppression in spice crops and future prospects. (Abstract-01-37), Seminar on biological control and Plant Growth Promoting Rhizobacteria (PGPR) for sustainable agriculture, Dept. of Biosciences, School of Life Sciences, University of Hyderabad.

Singh RA, Pavgi MS. 1966.Stem rot of rice in U.P, India. Phytopatho. 57(2):24-28.

Tarek A, Moussa A. 2002. Studies on Biological Control of Sugarbeet Pathogen Rhizoctonia solani Kuhn. OnLine Journal of Biological Sciences. 2(12): 800-804.

Ureta A, Alvarez B, Ramon A, Vera MA, Martinez G.1995. Identification of Acetobacter diazotrophicus, Herbaspirillum seropedicae and Herbaspirillum rubrisubalbicans using biochemical and genetic criteria. Plant Soil. 172:271-277.

Vasudevan P, Kavitha S, Brindha VP, Babujee L, Gnanamanickam SS. 2002.Biological Control of Rice
Diseases. in S.S. Gnanamanickam, eds. Biological Control of Crop Diseases. pp. 11-32.

Velazhahan R, Samiyappan R, Vidhyasekaran P.1999.Relationship between antagonistic activities of Pseudomonas fluorescens isolates against Rhizoctonia solani and their production of lytic enzymes. Zeitscrift fur Pflanzenkrankheiten und Pflan zenschutz. 106: 244-250.

Vidhyasekaran P, Muthamilan M. 1995. Development of formulations of Pseudomonas fluorescens for control of chick pea wilt. Plant Disease.79:782786.

Vidyasekaran P, Rabindran R, Muthamilan M. 1997. Development of a powder formulation of Pseudomonas fluorescens for control of rice blast. Plant Pathol. 46: 291-297.

Voisard C, Keel C, Haas D, Defago G. 1989. Cyanide production by Pseudomonas fluorescens helps suppress black root of tobacco under genobiotic conditions. EMBO. J. 8: 351-358.

Weller DM.1988. Biological control of soil borne plant pathogens in the rhizosphere with bacteria. Ann. Rev. Phyto. 26:379-40.

Whipps JM.1997. Developments in the biological control of soil borne pathogens. Advance Botanical Research. 26: 1-34.

\section{How to cite this article:}

Subhalakshmi, T. and Indira Devi, S. 2019. Biocontrol of Sclerotium oryzae by Pseudomonas fluorescens and Trichoderma spp. Isolated from Rice Rhizosphere of Indo- Burma Biodiversity Hotspot with Reference to Manipur. Int.J.Curr.Microbiol.App.Sci. 8(02): 2928-2941. doi: https://doi.org/10.20546/ijcmas.2019.802.341 